\title{
Characteristics of planktonic and sediment bacterial communities in a heavily polluted urban river
}

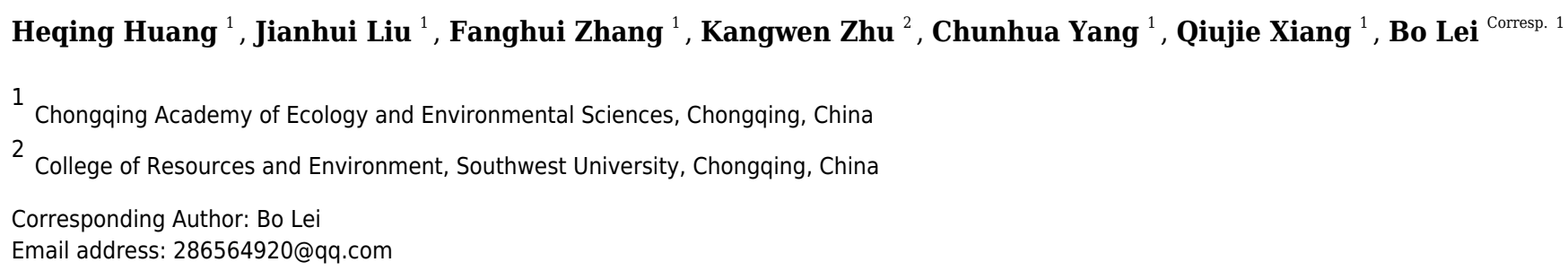

Urban rivers represent a unique ecosystem in which pollution occurs regularly, altering the biogeochemical characteristics of waterbodies and sediments. However, little is presently known about the spatiotemporal patterns of planktonic and sediment bacterial community diversities and compositions in urban rivers. Herein, Illumina MiSeq high-throughput sequencing was performed to reveal the spatiotemporal dynamics of bacterial populations in Liangtan River, a heavily polluted urban river in Chongqing City (China). The results showed the richness and diversity of sediment bacteria were significantly higher than those of planktonic bacteria, whereas a strong overlap (46.7\%) in OTUs was identified between water and sediment samples. Bacterial community composition remarkably differed in waters and sediments. Planktonic bacterial communities were dominated by Proteobacteria, Bacteroidetes, Cyanobacteria and Actinobacteria, while sediment bacterial communities mainly included Proteobacteria, Actinobacteria, Chloroflexi and Bacteroidetes. Additionally, several taxonomic groups of potential bacterial pathogens showed an increasing trend in water and sediment samples from residential and industrial areas (RI). Variation partition analysis (VPA) indicated that temperature and nutrient were identified as the main drivers determining the planktonic and sediment bacterial assemblages. These results highlight that bacterial communities in the polluted urban river exhibit spatiotemporal variation due to the combined influence of environmental factors associated with sewage discharge and hydropower dams. 


\section{Characteristics of planktonic and sediment bacterial}

\section{2 communities in a heavily polluted urban river}

5 Heqing Huang ${ }^{1}$, Jianhui Liu ${ }^{1}$, Fanghui Zhang ${ }^{1}$, Kangwen Zhu², Chunhua Yang ${ }^{1}$, Qiujie Xiang ${ }^{1}$,

6 Bo Lei ${ }^{1 *}$

81 Chongqing Academy of Ecology and Environmental Science, Chongqing, 401147, China

92 College of Resources and Environment, Southwest University, 400716, China

11 Corresponding Author: Bo Lei ${ }^{1}$

12 Street Qilong, Chongqing, Chongqing Academy of Environmental Science, 401147, China

13 Email address: 286564920@qq.com 


\section{Abstract}

16 Urban rivers represent a unique ecosystem in which pollution occurs regularly, altering the

17 biogeochemical characteristics of waterbodies and sediments. However, little is presently known

18 about the spatiotemporal patterns of planktonic and sediment bacterial community diversities and

19 compositions in urban rivers. Herein, Illumina MiSeq high-throughput sequencing was

20 performed to reveal the spatiotemporal dynamics of bacterial populations in Liangtan River, a

21 heavily polluted urban river in Chongqing City (China). The results showed the richness and

22 diversity of sediment bacteria were significantly higher than those of planktonic bacteria,

23 whereas a strong overlap (46.7\%) in OTUs was identified between water and sediment samples.

24 Bacterial community composition remarkably differed in waters and sediments. Planktonic

25 bacterial communities were dominated by Proteobacteria, Bacteroidetes, Cyanobacteria and

26 Actinobacteria, while sediment bacterial communities mainly included Proteobacteria,

27 Actinobacteria, Chloroflexi and Bacteroidetes. Additionally, several taxonomic groups of

28 potential bacterial pathogens showed an increasing trend in water and sediment samples from

29 residential and industrial areas (RI). Variation partition analysis (VPA) indicated that season and

30 nutrient were identified as the main drivers determining the planktonic and sediment bacterial

31 assemblages. These results highlight that bacterial communities in the polluted urban river

32 exhibit spatiotemporal variation due to the combined influence of environmental factors

33 associated with sewage discharge and hydropower dams.

35 Keywords: Urban river; Bacterial community structure; Diversity; Illumina MiSeq high-

36 throughput sequencing; Sewage discharge 


\section{Introduction}

40 Bacteria are the important components of river ecosystems and play a vital role in

41 biogeochemical processes of nutrients and biotransformation of organic matter (Madsen et al.,

42 2002; Wang et al., 2017). Bacteria communities are extremely sensitive to environmental

43 perturbations and serve as potential integrative indicators for measuring the stability of river

44 ecosystems (Marshall et al., 2008; Zhang et al., 2016). Therefore, it is particularly critical to

45 unravel the bacterial community diversity and structure to understand the responses of bacteria to

46 elevated environmental pressures in urban rivers (Crump et al., 2007; Quan et al., 2010).

Several previous studies have documented the shift in planktonic bacterial community diversity and composition can be influenced by water physicochemical properties including organic matter, nitrogen, phosphorus, pH, and temperature (Esteves et al., 2015; Fortunato et al., 2013;

Liu et al., 2012; Paudel et al., 2019; Yang et al., 2019; Zhang et al., 2019). Some of these influential factors might collectively regulate planktonic bacterial assemblages in river ecosystems. Moreover, the distribution of sediment bacterial community in river ecosystems has received increasing attention. A number of determined environmental factors have been proposed to play a pivotal role in river sediment bacterial communities including organic matter, nitrogen, phosphorus, pH and heavy metal (Bouskill et al., 2009; Peng et al., 2019; Su et al., 2019; Xia et al., 2014; Xie et al., 2016). However, water column and sediments are two different habitats in river ecosystems, characterized by distinctive properties, which result in profound dissimilarity of planktonic and sediment bacterial communities (Liu et al., 2018; Mao et al., 2019). Thus, there is a need for comparative analysis of planktonic and sediment bacterial 
61 communities in river ecosystems and their driving factors, given the heterogeneity of habitats in

62 space and time.

63

64 Compared with natural aquatic ecosystems, urban rivers represent a heterogeneous ecosystem that is mainly influenced by the surrounding terrestrial environment (Kaestli et al., 2017).

Sewage from the residential and industrial areas containing excessive pollutants notably alters the basic parameters of water and sediments, such as dissolved oxygen, nitrogen, temperature, and $\mathrm{pH}$, which could further reshape the bacterial community structure and diversity (Drury et al., 2013; Esteves et al., 2015; Mark Ibekwe et al., 2016). Sewage also introduces microbiological contamination (i.e. bacterial pathogens) to the urban aquatic ecosystems which can impact the composition and function of bacterial community (Drury et al., 2013; Mark Ibekwe et al., 2016). Additionally, construction of dams considerably modifies water discharge, regulate flow circulation and disturb nutrient transport by retaining suspended materials, thereby

74 altering the hydrodynamic condition of rivers and the distribution of bacterial community (Dai et al., 2013; Yan et al., 2015). Substantial differences in bacterial community composition have been observed between the upstream and downstream of dams (Ruiz-Gonzalez et al., 2013; Liu et al., 2018). However, the joint effects of sewage discharge and dam construction on bacterial communities in a certain urban river remain inadequately understood.

Considering this background, the biogeography of bacterial communities was studied in Liangtan

81 River, a heavily polluted urban river in Chongqing City, China. Specifically, the aim of this

82 current study was to investigate the spatiotemporal dynamics of both planktonic and sediment

83 bacterial populations in the urban river and their responses to dam construction and sewage 
84 discharge. Our findings will improve the understanding of multiple environmental gradients on

85 bacterial communities and provide an ecological reference for assessing urban aquatic 86 ecosystems.

\section{Materials \& Methods}

\section{Sites description and sample collection}

Liangtan River (watershed area of $498 \mathrm{~km}^{2}$ and mainstream length of $88 \mathrm{~km}$ ), located in Chongqing City (China), is one of major tributaries of Jiangling River. As a typical urban river, Liangtan River is completely surrounded by residential and industrial areas. Excessive anthropogenic input results in the deterioration of this urban river. Based on the Environmental Quality Standards for Surface Water of China, the water quality in all sections of Liangtan River has always been classified as worse than grade 5 (Ran et al., 2016). In this study, five different sampling sites were selected from upstream to downstream in Liangtan River (Figure 1). The distance between two adjacent sampling sites is approximately $8-12 \mathrm{~km}$. Sites L1 and L2 are located downstream and upstream of Xiema hydropower station (named as HS), respectively. Sites L3, L4, and L5 are surrounded by residential and industrial areas (named as RI), where the increasing anthropogenic activities have had a great impact on the health of the river ecosystem. Additionally, Sites L3 and L4 are adjacent to Xiyong and Tuzhu sewage plants, respectively. The sewage runoff from RI area is mainly composed of domestic pollution such as feces, nitrogen, and phosphorus etc. Triplicate water samples (30 $\mathrm{cm}$ depth below water surface, about $10 \mathrm{~L}$ ) and surface sediments $(0-10 \mathrm{~cm})$ were collected from the five sampling sites of Liangtan River in February (winter; the average air temperature is $10-25^{\circ} \mathrm{C}$; the average rainfall is $59.8 \mathrm{~mm}$ ) and August (summer; the average air temperature is $20-29^{\circ} \mathrm{C}$; the average rainfall is $438.3 \mathrm{~mm}$ ) in 
107 2019, using plexiglass water sampler and tube core sampler, respectively. These water samples

108 and surface sediments were placed in sterile containers and immediately transported to the

109 laboratory for subsequent chemical and molecular analysis.

110 The physicochemical properties $\left(\mathrm{pH}\right.$, temperature, ammonia nitrogen $\left(\mathrm{NH}_{4}{ }^{+}-\mathrm{N}\right)$, nitrate nitrogen

$111\left(\mathrm{NO}_{3}^{-}-\mathrm{N}\right)$, total nitrogen (TN), total phosphorus (TP), and total organic carbon (TOC)) of water

112 and sediment samples were measured following the methods described in literature (China

113 Environmental Protection Agency, 2002; Wang, 2012) and were shown in Tables S1 and S2,

114 respectively.

115

116 Molecular analyses

117 In the present study, $0.22-\mu \mathrm{m}$ pore-size membrane (diameter $50 \mathrm{~mm}$; Millipore) was used to

118 retain water microbial cells. Genomic DNA of water and sediment samples were extracted using

119 E.Z.N.A. Water DNA kit (Omega, USA) and Powersoil DNA extraction kit (Mobio

120 Laboratories, USA), respectively, according to manufacturer instructions. The V3-V4 region of

121 bacterial 16S ribosomal RNA (rRNA) gene was amplified using the primer sets 338F (5'-

122 ACTCCTACGGGAGGCAGCAG-3')/806R (5'- GGACTACHVGGGTWTCTAAT-3'), as

123 previously described ( $\mathrm{Xu}$ et al., 2016). The amplicons from each triplicate sample were pooled in

124 equal amounts and sequenced on an Illumina MiSeq platform at Shanghai Majorbio Bio-pharm

125 Technology Co., Ltd (China). The obtained raw reads were deposited in the NCBI Sequence

126 Read Archive (SRA) database under accession numbers SRP248929 for water and sediment

127 samples. The reads from the original DNA fragments were merged using FLASH and further

128 processed following the protocol by Caporaso et al. (2010). Chimeric reads were discarded

129 using UCHIME (Edgar et al., 2011). Sequences were assigned to their corresponding samples 
130 according to the barcode sequence and then quality-trimmed with an average Phred quality score

131 cutoff of 20. After quality filtering and the removal of chimeric sequences, data analyses were

132 performed to standardize the sequencing effort across samples. Chimeric-free sequences sharing

$133 \geq 97 \%$ similarity were grouped into operational taxonomic units (OTUs) and alpha-diversity

134 (Chao1 richness estimator, Shannon diversity index, and Simpson evenness index) was further

135 obtained using the UPARSE pipeline (Edgar, 2013). The representative sequences of each OTU

136 were classified with the Ribosomal Database Project (RDP) classifier (Wang et al., 2007).

\section{Statistical analysis}

139 One-way analysis of variance (ANOVA), followed by Fisher's least significant difference (LSD)

140 test, was used to determine significant differences $(\mathrm{P}<0.05)$ between alpha-diversity indices

141 and the relative abundances of potential bacterial pathogens among sample groups. Potential

142 relationships between physicochemical properties and (i) bacterial community richness; (ii)

143 diversity; and (iii) the proportion of the major bacterial groups were examined with Spearman

144 rank correlation analysis using the software SPSS 20.0.

145 To elucidate the microbial interactions of different environments, molecular ecological networks

146 were constructed in Molecular Ecological Network Analysis pipeline (MENA,

147 http://ieg4.rccc.ou.edu/mena/). Person correlation analysis based on random matrix theory

148 (RMT) was used to construct networks. Each network analysis used bacterial OTUs data from

149 ten samples in every ecosystem. OTUs detected in more than half of the samples were kept for

150 the network construction as default settings in the pipeline to ensure the accuracy of OTUs

151 interrelationships. Global network properties, individual nodes' centrality, and module separation

152 and modularity were calculated. Among these properties, each node is an estimable molecular 
153 marker (e.g. OTU) and each edge (e.g. interaction) represents the strength of the correlation

154 between them. Logarithm transitivity was used to infer the stability of the community. The

155 constructed network graphs were visualized by Cytoscape (version 3.7.2) and Gephi software

156 (version 0.9.2).

157 To examine the difference in the overall community composition between each pair of samples

158 at the OTU level, Beta-diversity using Bray-Curtis dissimilarities (Bray and Curtis, 1957) was

159 used to examine the difference in the overall community composition between samples and

160 visualized on a PCoA plot. Permutational multivariate analysis of variance (PerMANOVA) was

161 performed to test for significant differences between sample groups based on Bray-Curtis

162 distance matrices. Multivariate analysis was used to determine which physicochemical properties

163 had the biggest impact on planktonic and sediment bacterial communities. Detrended

164 correspondence analysis (DCA) was first applied to determine the suitable ordination analysis

165 method for exploring the correlations between overall bacterial community composition (OTU

166 level) and the environmental factors. The longest DCA axis had a gradient length less than 3

167 standard deviation units, so redundancy analysis (RDA) was performed (Lepš and Šmilauer,

168 2003; Li et al., 2019). Variance inflation factor (VIF) was used for multicollinearity among

169 environmental variables; variables with VIF > 10 were eliminated from RDA analysis. Variation

170 partition analysis (VPA) was applied for assessing the individual and shared effects of season

171 (temperature and rainfall), nutrient $\left(\mathrm{NH}_{4}{ }^{+}-\mathrm{N}, \mathrm{NO}_{3}{ }^{-}-\mathrm{N}, \mathrm{TN}, \mathrm{TP}\right.$, and TOC) and geographic

172 distance (latitude and longitude) on planktonic and sediment bacterial community structures.

173 Species data were log transformed and environmental data were z-score standardized prior to

174 beta-diversity calculations. R (version 4.0.2) was used for statistical testing unless otherwise 
175 indicated. PCoA, PerMANOVA, DCA, RDA, VIF and VPA were performed using the "vegan"

176 package.

177

178 Results

179 Bacterial community richness and diversity

180 In this study, the obtained high-quality bacterial reads from each sample ranged between 28,133

181 and 63,295, normalized to 28,133 for the comparison of bacterial community richness and

182 diversity. High Good's coverage indicated that the OTUs of each bacterial library had been well

183 captured, with the values ranging from $95.5 \%$ to $98.4 \%$. Water bacterial libraries were

184 composed of 1,706-2,783 OTUs, while sediment bacterial libraries comprised 3,488-4,731

185 OTUs (Table S1). The Chao1 richness estimators of planktonic and sediment bacterial

186 communities were 2,865-3,810 and 4,083-6,015, respectively. At a given sampling site,

187 sediment sample was generally found to have more OTUs and higher Chaol richness estimator

188 than the corresponding water one. Additionally, a significant increase of planktonic bacterial

189 richness was observed in summer $(\mathrm{P}<0.05)$ (Figure 2$)$, yet the trend of seasonal variation of

190 sediment bacterial richness was not clear. Shannon and Simpson indices of planktonic bacterial

191 communities were 4.49-5.20 and 0.0208-0.0449, while those of sediment bacterial communities

192 were 6.40-7.09 and 0.002-0.009. In summer, Shannon and Simpson indices of both planktonic

193 and sediment bacterial communities in HS area were significantly different from those in RI area

$194(\mathrm{P}<0.05)$. However, a significant seasonal difference of sediment bacterial diversity (Shannon

195 and Simpson indices) was only observed in $\mathrm{RI}$ area $(\mathrm{P}<0.05)$.

196 
197 In order to explore the interactions between water and sediment bacterial communities, the OTUs

198 were used to construct Microbial Ecological Networks (MENs) (Figure S1 and S2). 46.7\% of

199 OTUs were shared between water and sediment samples. Water samples contained 1273 unique

200 OTUs that accounted for $14.0 \%$ of the total OTUs. The sediment network contained 2801 edges

201 among 1746 nodes, which were fewer than the networks of water (9927 edges among 795

202 nodes), reflecting a smaller number of co-occurrences in sediment (edge/node ratio=1.60). The

203 decreases in average connectivity and average clustering coefficient further demonstrated a

204 reduction in network complexity from water to sediment (Table S2). Additionally, 51.3\%

205 positive edges and $48.7 \%$ negative edges were presented in sediment while $47.5 \%$ positive edges

206 and 52.5\% negative edges showed in water. These results show that the topological features

207 between water and sediment were distinguishable, and the interactions among the bacterial

208 communities in water were much complex than that in sediment. The results of PCoA analysis

209 revealed a marked discrepancy in the structure of planktonic and sediment bacterial communities

210 (Figure 3). PerMANOVA confirmed that the bacterial communities in the water were

211 significantly different from those in the sediment $\left(\mathrm{R}^{2}=0.561, \mathrm{P}=0.001\right)$ (Table 1$)$. Planktonic

212 bacterial communities for summer samples significantly differed from winter samples $\left(\mathrm{R}^{2}=\right.$

$2130.731, \mathrm{P}=0.011$ ), yet the trend for seasonal change of sediment bacterial community structure

214 was not apparent. An obvious and significant difference of sediment bacterial communities was

215 found between $\mathrm{HS}$ and $\mathrm{RI}$ areas $\left(\mathrm{R}^{2}=0.345, \mathrm{P}=0.006\right)$. Additionally, the interaction effects of

216 seasons (winter or summer) and areas (HS or RI) on planktonic and sediment bacterial

217 communities were statistically significant $\left(\mathrm{R}^{2}=0.886, \mathrm{P}=0.002 ; \mathrm{R}^{2}=0.886, \mathrm{P}=0.002\right.$,

218 respectively).

219 
221 In the present study, a total of 13 major bacterial phyla (relative abundance $>1 \%$ in each

222 sample) were identified, including Proteobacteria, Bacteroidetes, Actinobacteria, Chloroflexi, 223 Cyanobacteria, Firmicutes, Acidobacteria, Epsilonbacteraeota, Patescibacteria,

224 Gemmatimonadetes, Spirochaetes, Nitrospirae, and Latescibacteria (Figure 4). Proteobacteria

225 showed the dominance in the water samples (39.9-54.8\%) and sediment samples (28.0-48.4\%),

226 mainly consisting of three classes (Alphaproteobacteria, Gammaproteobacteria, and

227 Deltaproteobacteria) (Figure 5). Gammaproteobacteria predominated proteobacterial classes

228 across all samples, and was relatively higher in water samples. Moreover, winter water samples

229 generally had higher Gammaproteobacteria proportion than summer samples, yet the seasonal

230 variation of Gammaproteobacteria organisms in sediments was not clear. Alphaproteobacteria

231 was the second largest proteobacterial class in all samples, but the abundance of planktonic

232 Alphaproteobacteria organisms revealed an evident decrease in winter. Deltaproteobacteria was

233 also an important proteobacterial member in sediment, but showed lower proportion in water.

234 The second largest bacterial phylum in water samples was Bacteroidetes (10.7-26.5\%), but its

235 proportion was relatively low in sediment samples (6.1-13.3\%). However, Actinobacteria and

236 Firmicutes were more prevalent in sediment samples (Actinobacteria 7.1-19.5\%, Firmicutes

237 4.1-8.7\%) than those in water samples (Actinobacteria 3.9-15.4\%, Firmicutes 1.5-5.2\%).

238 Additionally, Chloroflexi and Acidobacteria showed relatively high proportion in sediment

239 samples, but became the minor planktonic bacterial groups. In contrast, Cyanobacteria and

240 Epsilonbacteraeota, as two major components of planktonic bacterial communities, were rarely

241 detected in sediments.

242 
243 To determine the heterogeneity of potential bacterial pathogens at the genus level among the

244 sample groups, a total of 12 major bacterial genus (relative abundance $>0.1 \%$ in each sample)

245 were detected, including Pseudomonas, Arcobacter, Aeromonas, Escherichia-Shigella,

246 Legionella, Acinetobacter, Enterobacter, Bacteroides, Flavobacterium, Mycobacterium,

247 Bacillus, and Clostridium (Table S3). Water samples were generally found to have a higher

248 proportion of bacterial pathogens as mentioned above than sediment samples. In either summer

249 or winter, the average relative abundance of potential bacterial pathogens in water and sediment

250 samples from RI area was significantly higher than those from HS areas $(\mathrm{P}<0.05)$ (Table 2).

252 Influential factors on bacterial communities

253 Spearman rank correlation analysis indicated that planktonic bacterial community richness (OTU 254 number and Chaol estimator) and the taxa (Proteobacteria and Alphaproteobacteria) displayed 255 positive correlations with the water temperature $(\mathrm{P}<0.05$ or $\mathrm{P}<0.01)$, but were negatively 256 correlated to TP $(\mathrm{P}<0.05$ or $\mathrm{P}<0.01)$ (Table 3$)$. Planktonic bacterial community Shannon 257 diversity showed a significant negative correlation with water $\mathrm{NH}_{4}{ }^{+}-\mathrm{N}$ and TOC concentrations 258 ( $\mathrm{P}<0.05)$. Moreover, Bacteroidetes displayed a negative correlation with $\mathrm{TN}$ and $\mathrm{TP}(\mathrm{P}<0.05)$, 259 while Cyanobacteria was positively correlated to $\mathrm{NH}_{4}{ }^{+}-\mathrm{N}, \mathrm{TN}$, and TOC $(\mathrm{P}<0.05)$. In addition, 260 water temperature and TP were identified as key drivers determining the abundance of

261 Actinobacteria $(\mathrm{P}<0.05)$. Water temperature also positively correlated to Patescibacteria $(\mathrm{P}<$ 262 0.05). The results of RDA analysis revealed that the water environmental factors in the first two 263 RDA axes respectively accounted for $59.1 \%$ and $24.3 \%$ of the total variance for planktonic

264 bacterial OTU composition (Figure 6). Rainfall (F=7.31, $\mathrm{P}=0.012$, 499 Monte Carlo 265 permutations), water temperature $(\mathrm{F}=6.93, \mathrm{P}=0.006,499$ Monte Carlo permutations $), \mathrm{TP}(\mathrm{F}=4.05$ 
$\mathrm{P}=0.028$, 499 Monte Carlo permutations), and $\mathrm{TN}(\mathrm{F}=4.00 \mathrm{P}=0.022$, 499 Monte Carlo

267 permutations) significantly contributed to the planktonic bacterial population-environment relationship. The VPA indicated that season, nutrients, and geographic distance explained 78.7\% of the variation in the planktonic bacterial community (Figure 7a). Season, nutrients, and geographic distance explained $42.5 \%, 18.1 \%$, and $13.7 \%$ of the total variation, respectively.

Therefore, the variation in planktonic bacterial community was mainly determined by season and

272 nutrient condition.

Sediment bacterial Shannon diversity exhibited a positive correlation with sediment $\mathrm{NH}_{4}{ }^{+}-\mathrm{N}$, $\mathrm{NO}_{3}{ }^{-}-\mathrm{N}$, and $\mathrm{TN}$ concentrations $(\mathrm{P}<0.05)($ Table 4). Proteobacteria was negatively correlated to $\mathrm{NH}_{4}{ }^{+}-\mathrm{N}$ and $\mathrm{NO}_{3}{ }^{-}-\mathrm{N}(\mathrm{P}<0.05)$, while Deltaproteobacteria displayed a positive correlation with sediment $\mathrm{pH}(\mathrm{P}<0.01)$. Moreover, Alphaproteobacteria were positively correlated to the water temperature $(\mathrm{P}<0.05)$, but negatively correlated to TP and TOC $(\mathrm{P}<0.01)$.

Actinobacteria was positively correlated to $\mathrm{NH}_{4}{ }^{+}-\mathrm{N}, \mathrm{NO}_{3}{ }^{-}-\mathrm{N}$, and $\mathrm{TN}(\mathrm{P}<0.05)$, while Acidobacteria showed a negatively correlation with $\mathrm{NH}_{4}{ }^{+}-\mathrm{N}, \mathrm{NO}_{3}{ }^{-}-\mathrm{N}$, and $\mathrm{TN}(\mathrm{P}<0.05)$.

281 Chloroflexi was found to be related to sediment $\mathrm{pH}$, TP, and TOC $(\mathrm{P}<0.05$ or $\mathrm{P}<0.01)$.

Additionally, Gemmatimonadetes and Nitrospirae were positively correlated to $\mathrm{NH}_{4}{ }^{+}-\mathrm{N}$ and $\mathrm{NO}_{3}{ }^{-}-\mathrm{N}(\mathrm{P}<0.05$ or $\mathrm{P}<0.01)$, while Bacteroidetes showed a positive correlation with sediment

$284 \mathrm{TP}$ and TOC concentrations $(\mathrm{P}<0.05$ or $\mathrm{P}<0.01)$. RDA analysis for sediment communities 285 showed that sediment physicochemical factors explained $44.5 \%$ and $31.4 \%$ of the total variation 286 (Figure 8), respectively. Sediment TP (F=3.89, $\mathrm{P}=0.006,499$ Monte Carlo permutations), rainfall $287(\mathrm{~F}=3.38, \mathrm{P}=0.016,499$ Monte Carlo permutations $)$ and temperature $(\mathrm{F}=3.38, \mathrm{P}=0.012,499$ 288 Monte Carlo permutations) passed the Monte Carlo significance test $(\mathrm{P}<0.05)$, suggesting a 
289 significant contribution to the sediment bacterial community composition-environment

290 relationship. The VPA showed the season, nutrients, and geographic distance contributed 69.1\%

291 of the variation in the sediment bacterial community (Figure 7b). Season and nutrients explained

$29254.4 \%$ of the variation, indicating a major contribution in shaping the sediment bacterial 293 community.

295 Discussion

Bacterial community richness and diversity in Liangtan river

297 Numerous previous studies have shown the spatiotemporal variation of bacterial community

298 richness and diversity in aquatic ecosystems (Adhikari et al., 2019; Dai et al., 2016; Mai et al., 299 2018; Mao et al., 2019; Yang et al., 2019; Sheng et al., 2016; Zhang et al., 2014; Zhang et al., 300 2019; Zhu et al., 2019). However, little is known about the shift of bacterial richness and 301 diversity in given urban rivers. In this study, Illumina Miseq high-throughput sequencing was 302 used to reveal the richness and diversity of planktonic and sediment bacterial communities in 303 Liangtan river. The Chao1 richness estimators and Shannon diversity index of planktonic 304 bacterial communities were 2,865-3,810 and 4.49-5.20, while those of sediment communities 305 were 4,083-6,015 and 6.40-7.09, respectively. However, lower Chao1 richness estimator but 306 higher Shannon diversity index of both planktonic and sediment bacterial communities were 307 detected in Jiangling river, the mainstream of Liangtan river (Wang et al., 2018). Additionally, 308 the Chaol richness and Shannon diversity of sediment in Liangtan river were markedly higher 309 than those of their corresponding water column, which were in agreement with previous studies 310 in river systems (Dai et al., 2016; Mao et al., 2019; Staley et al., 2015). In this study, a

311 remarkable seasonal fluctuation of planktonic bacterial community richness occurred in Liangtan 
312 river, but the trend of seasonal variation of sediment community diversity was not clear.

313 Moreover, significant differences in Shannon diversity of both planktonic and sediment bacterial

314 communities were observed between HS and RI areas in summer $(\mathrm{P}<0.05)$, suggesting that the

315 spatial distribution of bacterial communities. The spatial change of bacterial community diversity

316 was dependent on sampling date. Dai et al. (2016) indicated a remarkable spatial variation of

317 bacterial Shannon diversity in summer compared to spring, which further supported the results.

319 Previous literatures suggest that planktonic bacterial community richness or/and diversity in river 320 ecosystems might be influenced by water temperature, $\mathrm{pH}$, and nutrients (Mao et al., 2019;

321 Staley et al., 2015; Wang et al., 2016). The results of Spearman rank correlation analysis

322 revealed that water temperature and TP were the dominant driving forces for planktonic bacterial 323 community richness, while $\mathrm{NH}_{4}{ }^{+}-\mathrm{N}$ and TOC were identified as key drivers determining 324 planktonic bacterial community Shannon diversity. Numerous influential factors on sediment

325 bacterial communities in river systems have been documented previously (Mao et al., 2019;

326 Zhang et al., 2019), where bacterial diversity was correlated with nutrients and heavy metals.

327 Sheng et al. (2016) indicated that increases in TN and TP may lead to high bacterial richness and 328 diversity. Our study identified the sediment bacterial Shannon diversity was positively correlated 329 to the level of sediment $\mathrm{NH}_{4}{ }^{+}-\mathrm{N}, \mathrm{NO}_{3}{ }^{-}-\mathrm{N}$, and $\mathrm{TN}$, yet no determined indicators could well 330 explain the sediment bacterial richness.

332 Bacterial community composition in Liangtan river

333 There is a large degree of variation in bacterial communities in terms of taxonomic composition

334 in aquatic ecosystems (Adhikari et al., 2019; Chen et al., 2018; Dai et al., 2016; Mai et al., 
335

336

337

338

339

340

341

342

343

344

345

346

347

348

349

350

351

352

353

354

355

356

357

2018; Sun et al., 2019; Xia et al., 2014; Yang et al., 2019; Zhang et al., 2014; Zhu et al., 2019),

whereas the characteristics of bacterial communities in given urban rivers remains poorly

understood. In this study, the results of PCoA and PerMANOVA revealed strong heterogeneity

in the structure of planktonic and sediment bacterial communities, which was supported by

previous studies in river systems (Ibekwe et al., 2016; Liu et al., 2018; Staley et al., 2015; Wang

et al., 2018). However, a strong overlap (46.7\%) in OTUs was identified between water and

sediment samples from Liangtan river. The coexisting bacteria accounted for $76.9 \%$ of the whole

communities in water column, indicating that planktonic bacterial communities was mostly

seeded from sediment bacterial communities. As proposed by Staley et al. (2015), sediment can

contribute up to $50 \%$ of the community composition in the water column explaining the big

overlap. The positive and negative correlation in water and sediment accounted for nearly $50 \%$,

indicating a similar co-occurrence patterns that complex ecological relationships (e.g. symbiosis,

competition, or predation) in both water and sediment. However, a higher co-occurrence were

found in water, which might be attributed to environmental filtering and niche differentiation.

The most abundant phylum in water and sediment of Liangtan river was Proteobacteria, which

was in line with previous studies in river ecosystems (Liu et al., 2012; Liu et al., 2018; Mao et

al., 2019; Staley et al.,2015; Tao et al.,2019; Wang et al., 2018; Zhang et al., 2019). Noticeably,

the genera Pseudomonas, Arcobacter, Acinetobacter belonging to phylum Proteobacteria were

detected in high abundance in water and/or sediment samples. Additionally, taxa displayed

higher abundances in the RI area compared to the HS area (Table S3) that may be attributed to

the high nutrient sources from industrial and residential sewage. Newton et al. (2013) identified

three bacterial genera (Acinetobacter, Arcobacter, and Trichococcus) as sewer signatures in

urban wastewater. Yang et al. (2019) revealed that members of genus Acinetobacter comprise of 
358 potentially pathogenic as well as sewage indicator bacteria. Bacteroidetes was the second largest

359 phylum in the water samples from Liangtan river. Specific species within this phylum are

360 associated with the gut microbiota of many mammals (Shanks et al., 2011) and humans (Candela

361 et al., 2010). Consequently, Bacteroidetes might be proposed as effective alternative fecal

362 indicators (Wéry et al., 2008). In our study, water samples from RI area generally had higher

363 abundance of the potential pathogenic bacteria Bacteroides (phylum Bacteroidetes) than those

364 from HS area (Table S3). Another indicator of fecal contamination is Firmicutes, which is one of

365 the markers for identifying human feces (Zheng et al., 2009). The relative abundance of

366 Firmicutes was higher in sediment samples than that in water samples. Interestingly, the genera

367 Bacillus and Clostridium (phylum Firmicutes) were found mainly in sediment samples from RI

368 area associated with the presence of untreated fecal sewage.

369

370 Cyanobacteria was another predominant group of planktonic bacterial communities in Liangtan

371 river. A remarkable increase of Cyanobacteria abundance in site L2 compared to that in site L1

372 was detected which might be associated with hydropower station. Similar observations were

373 documented for the Guadiana river (Domingues et al., 2014) and Jiangling river (Wang et al.,

374 2018). The impact of dam construction was predicted to increase eutrophication conditions and

375 possibly promote Cyanobacteria blooms (Wang et al., 2018). Additionally, the abundance of

376 Cyanobacteria in our study was positively correlated to water $\mathrm{NH}_{4}{ }^{+}-\mathrm{N}, \mathrm{TN}$, and TOC

377 concentrations, suggesting its potential to serve as an important indicator of river eutrophication.

378 These results suggest environmental dominators drive the potentially responses of bacterial

379 community structure to the domestic sewage-polluted conditions and construction of hydropower 380 station. 
382 The VPA revealed a major contribution of season and nutrients in shaping planktonic and

383 sediment bacterial communities, yet the effect of geographical distance on bacterial community

384 structure was negligent. Environmental factors are more likely to contribute to variation in

385 bacterial composition than geographical distance at small or intermediate spatial scales (less than

3863000 km; Martiny et al. 2006). Hence, environmental factors (season and nutrients) were more

387 important than geographical distance in shaping bacterial community structure in Liangtan River.

388 Specifically, the results of RDA suggested that rainfall, water temperature, TP, and TN between

389 seasons mainly accounted for the shift of the planktonic bacterial community structure, while TP,

390 rainfall and temperature were identified as key drivers determining sediment bacterial

391 community composition. The fluctuations of rainfall and temperature between seasons may

392 mainly account for the seasonal variations in bacterial community structure. As proposed by

393 previous studies (Haque et al., 2018; Staley et al., 2015), seasonal hydrological regime (i.e.

394 rainfall) directly causes a "wash-out effect" of nutrients and bacterial assemblages. Additionally,

395 nutrients were found to be another key driver explaining bacterial community structure. Ibekwe et

396 al. (2016) highlighted that phosphorus and nitrogen are the major factors significantly related to

397 the changes in planktonic bacterial community. Zhang et al. (2019) also stressed the significant

398 roles of TP and temperature on the variation of sediment bacterial community.

399

400 Implications of the research

401 Sediments within aquatic ecosystems represent a complex matrix, usually

402 providing microorganisms with numerous advantages not found in the water column. 
403 Perkins et al. (2014) reported that sediments contain more nutrients than the water column, and

404 sediments can shield bacteria from the effect of sunlight and protect bacteria against predation.

405 In the current study, the sediment samples clustered distinctively from water samples and

406 displayed a higher bacterial diversity than the water samples, strengthening the fact that

407 sediments may serve as reservoirs of diverse microbial populations and highlighting the need to

408 include sediments in river monitoring. Additionally, the fecal bacteria and candidate pathogens

409 accounted for a higher proportion in RI area, suggesting their potential to serve as important

410 indicators for the health and status of river ecosystems. Nevertheless, more extensive researches

411 should be conducted in our future work, including (i) a long-term investigation (i.e. samples will

412 be collected seasonally during two years) of planktonic and sediment bacterial communities in

413 urban rivers polluted by continuous domestic sewage is of paramount importance; (ii) the role of

414 functional microorganisms, especially high abundance of bacterial pathogens, is furtherly

415 elucidated to provide insight into the monitoring and control of contamination in urban rivers.

\section{Conclusions}

418 Our study revealed a comprehensive understanding of the integrated biogeography of planktonic

419 and sediment bacterial communities in Liangtan river. Water and sediment habitats differed

420 greatly in bacterial community richness, diversity and structure. Additionally, the relative

421 abundance of potential bacterial pathogens in water and sediment samples from RI area was

422 significantly higher than those from HS area. Under the joint influence of sewage discharge and

423 hydropower dams, rainfall, temperature and nutrient were identified as the deterministic forces

424 shaping the bacterial communities in the heavily polluted urban river. Our study offers further

425 reference for the environmental management of Liangtan River. It also provides typical data for 
426 the comparison with other urban rivers, and thus contributes to the increasing knowledge of

427 microbial ecology in contaminated urban rivers.

428

429 References

430 Adhikari PN, Liu YQ, Liu KS, Zhang F, Adhikari S, Chen YY, Liu XB. 2019. Bacterial

431 community composition and diversity in Koshi River, the largest river of Nepal. Ecological

432 Indicators 104: 501-511 DOI 10.1016/j.ecolind.2019.05.009.

433 Bouskill NJ, Barker-Finkel J, Galloway TS, Handy RD, Ford TE. 2009. Temporal bacterial

434 diversity associated with metal-contaminated river sediments. Ecotoxicology (London, England)

435 19: 317-328 DOI 10.1007/s10646-009-0414-2.

436 Bray JR, Curtis JT. 1957. An ordination of the upland forest communities of southern

437 Wisconsin. Ecological Monographs 27(4): 325-349 DOI 10.2307/1942268.

438 Candela M, Consolandi C, Severgnini M, Biagi E, Castiglioni B, Vitali B, Gianluca DB,

439 Patrizia B. 2010. High taxonomic level fingerprint of the human intestinal microbiota by ligase

440 detection reaction - universal array approach. BMC Microbiology 10: 116 DOI 10.1186/1471-

441 2180-10-116.

442 Caporaso JG, Kuczynski J, Stombaugh J, Bittinger K, Bushman FD, Costello EK, Fierer N,

443 Peña AG, Goodrich JK, Gordon JI, Huttley GA, Kelley ST, Knights D, Koenig JE, Ley RE,

444 Lozupone CA, McDonald D, Muegge BD, Pirrung M, Reeder J. 2010. QIIME allows analysis

445 of high-throughput community sequencing data. Nature Methods 7: 335-336 DOI

446 10.1038/nmeth.f.303.

447 Chen Y, Jiang Y, Huang H, Mou L, Ru J, Zhao J, Xiao S. 2018. Long-term and high-

448 concentration heavy-metal contamination strongly influences the microbiome and functional 
449 genes in Yellow River sediments. Science of The Total Environment 637: 1400-1412 DOI

450 10.1016/j.scitotenv.2018.05.109.

451 China Environmental Protection Agency. 2002. Methods for water and wastewater

452 determination. China Environmental Science Press, Beijing.

453 Crump BC, Adams HE, Hobbie JE, Kling GW. 2007. Biogeography of bacterioplankton in

454 lakes and streams of an arctic tundra catchment. Ecology 88: 1365-1378 DOI 10.1890/06-0387.

455 Dai Y, Yang YY, Wu Z, Feng QY, Xie SG, Liu Y. 2016. Spatiotemporal variation of planktonic

456 and sediment bacterial assemblages in two plateau freshwater lakes at different trophic status.

457 Applied Microbiology and Biotechnology 100(9): 4161-4175 DOI 10.1007/s00253-015-7253-2.

458 Dai Z, Liu JT. 2013. Impacts of large dams on downstream fluvial sedimentation: an example of 459 the Three Gorges Dam (TGD) on the Changjiang (Yangtze River). Journal of Hydrology 480:104608 DOI 10.1016/j.jhydrol.2012.12.003.

461 Domingues RB, Barbosa AB, Sommer U, Galvão HM. 2012. Phytoplankton composition, 462 growth and production in the Guadiana estuary (SW Iberia): unraveling changes induced after 463 dam construction. Science of The Total Environment 416: 300-313 DOI 464 10.1016/j.scitotenv.2011.11.043.

465 Drury B, Rosi-Marshall E, Kelly JJ. 2013. Wastewater treatment effluent reduces the 466 abundance and diversity of benthic bacterial communities in urban and suburban rivers. Applied 467 and Environmental Microbiology 79: 1897-1905 DOI 10.1128/AEM.03527-12.

468 Edgar RC. 2013. UPARSE: highly accurate OTU sequences from microbial amplicon reads. 469 Nature Methods 10:996 DOI 10.1038/NMETH.2604. 
470 Edgar RC, Haas BJ, Clemente JC, Quince C, Knight R. 2011. UCHIME improves sensitivity

471 and speed of chimera detection. Bioinformatics 27:2194-2200 DOI

472 10.1093/bioinformatics/btr381.

473 Esteves KE, Lôbo AVP, Hilsdorf AWS. 2015. Abiotic features of a river from the Upper Tietê

474 River Basin (SP, Brazil) along an environmental gradient. Acta Limnologica Brasiliensia 27: 228475237.

476 Fortunato CS, Eiler A, Herfort L, Needoba JA, Peterson TD, Crump BC. 2013. Determining 477 indicator taxa across spatial and seasonal gradients in the Columbia River coastal margin. ISME 478 Journal 7:1899-1911 DOI 10.1590/S2179-975X5914 DOI 10.1038/ismej.2013.79.

479 Haque MA, Jewel MA, Atique U, Paul AK, Naher N, Iqbal S. 2020. Seasonal and spatial 480 variation of flagellate communities in a tropical river. Limnologica- Ecology and Management of 481 Inland Waters 85: 125824 DOI 10.1016/j.limno.2020.125824.

482 Ibekwe AM, Ma J, Murinda SE. 2016. Bacterial community composition and structure in an 483 Urban River impacted by different pollutant sources. Science of The Total Environment 484 566:1176-1185 DOI 10.1016/j.scitotenv.2016.05.168.

485 Kaestli M, Skillington A, Kennedy K, Majid M, Williams D, Mcguinness K, Munksgaard N, 486 Gibb K. 2017. Spatial and temporal microbial patterns in a tropical macrotidal estuary subject to 487 urbanization. Frontiers in Microbiology 8:1313 DOI 10.3389/fmicb.2017.01313.

488 Lepš J, Šmilauer P. 2003. Multivariate Analysis of Ecological Data Using CANOCO. NY: 489 Cambridge University Press, New York DOI 10.2136/vzj2004.1057.

490 Li Y, Gao Y, Zhang WL, Wang C, Wu HN. 2019. Homogeneous selection dominates the 491 microbial community assembly in the sediment of the Three Gorges Reservoir. Science of The 492 Total Environment 690: 50-60 DOI 10.1016/j.scitotenv.2019.07.014. 
493 Liu T, Zhang AN, Wang JW, Liu SF, Jiang XT, Dang CY, Ma T, Liu ST, Chen Q, Xie SG,

494 Zhang T, Ni JR. 2018. Integrated biogeography of planktonic and sedimentary bacterial

495 communities in the Yangtze River. Microbiome 6(1):16 DOI 10.1186/s40168-017-0388-x.

496 Liu Z, Huang S, Sun G, Xu Z, Xu M. 2012. Phylogenetic diversity, composition and distribution 497 of bacterioplankton community in the Dongjiang River, China. FEMS Microbiology. Ecology 80

498 (1): 30-44 DOI 10.1111/j.1574-6941.2011.01268.x.

499 Madsen EL. 2002. Microorganisms and their roles in fundamental biogeochemical cycles.

500 Current Opinion in Biotechnology 22:456-464 DOI 10.1016/j.copbio.2011.01.008.

501 Mai YZ, Lai ZN, Li XH, Peng SY, Chao W. 2018. Structural and functional shifts of

502 bacterioplanktonic communities associated with spatiotemporal gradients in river outlets of the

503 subtropical pearl river estuary, south china. Marine Pollution Bulletin 136:309-321 DOI

504 10.1016/j.marpolbul.2018.09.013.

505 Mao YF, Liu Y, Li H, He Q, Yang GF. 2019. Distinct responses of planktonic and sedimentary

506 bacterial communities to anthropogenic activities: Case study of a tributary of the Three Gorges

507 Reservoir, China. Science of The Total Environment. 682. DOI 10.1016/j.scitotenv.2019.05.172.

508 Mark Ibekwe A, Ma J, Murinda SE. 2016. Bacterial community composition and structure in

509 an Urban River impacted by different pollutant sources. Science of The Total Environment 566:

510 1176-1185 DOI 10.1016/j.scitotenv.2016.05.168.

511 Marshall MM, Amos RN, Henrich VC, Rublee PA. 2008. Developing SSU rDNA

512 metagenomic profiles of aquatic microbial communities for environmental assessments.

513 Ecological Indicators 8:442-453 DOI 10.1016/j.ecolind.2007.04.007. 
514 Martiny JB, Bohannan BJ, Brown JH, Colwell RK, Fuhrman JA, Green JL, Horner MC,

515 Kane M, Krumins JA, Kuske CR. 2006. Microbial biogeography: putting mi- croorganisms on

516 the map. Nature Reviews Microbiology 4: 102-112 DOI 10.1038/nrmicro1341.

517 Newton RJ, Bootsma MJ, Morrison HG, Sogin ML, Mclellan SL. 2013. A microbial signature

518 approach to identify fecal pollution in the waters off an urbanized coast of lake Michigan.

519 Microbial Ecology 65 (4): 1011-1023 DOI 10.1007/s00248-013-0200-9.

520 Peng FJ, Pan CG, Zhang NS, Braak CJ, Salvito D, Selck H, Ying GG, Brink PJ. 2019.

521 Benthic invertebrate and microbial biodiversity in sub-tropical urban rivers: Correlations with

522 environmental variables and emerging chemicals. Science of The Total Environment 709: 136281

523 DOI 10.1016/j.scitotenv.2019.136281.

524 Perkins TL, Clements K, Baas JH, Jago CF, Jones DL, Malham SK, McDonald JE. 2014.

525 Sediment composition influences spatial variation in the abundance of human pathogen indicator

526 bacteria within an estuarine environment. PLoS One 9(11): e112951 DOI

527 10.1371/journal.pone.0112951.

528 Quan X, Wang Y, Xiong W, He M, Yang Z, Lin C. 2010. Description of microbial community

529 structure of sediments from the Daliao River water system and its estuary (NE China) by

530 application of fluorescence in situ hybridization. Environmental Earth Sciences 61:1725-1734

531 DOI 10.1007/s12665-010-0486-6.

532 Ran T, Yuan QP, Zeng J, Qi J. 2016. Quantification study of river eco-compensation based on

533 multiple of ultra-standard of water quality concentration - a case study of liangtan river. Sichuan

534 Environment. 6: 52-56. 
535 Ruiz-Gonzalez C, Proia L, Ferrera I, Gasol JM, Sabater S. 2013. Effects of large river dam

536 regulation on bacterioplankton community structure. FEMS Microbiology Ecology 84: 316-331

537 DOI 10.1111/1574-6941.12063.

538 Shanks OC, Kelty CA, Archibeque S, Jenkins M, Newton RJ, McLellan SL, Huse SM, Sogin

539 ML. 2011. Community structures of fecal bacteria in cattle from different animal feeding

540 operations. Applied Microbiology and Biotechnology 77: 2992-3001 DOI 10.1128/AEM.02988-

54110.

542 Sheng P, Yu YZ, Zhang GH, Huang JL, He L, Ding JN. 2016. Bacterial diversity and

543 distribution in seven different estuarine sediments of Poyang Lake, China. Environmental Earth

544 Ences 75(6):479 DOI 10.1007/s12665-016-5346-6.

545 Staley C, Gould TJ, Wang P, Phillips J, Cotner JB, Sadowsky MJ. 2015. Species sorting and

546 seasonal dynamics primarily shape bacterial communities in the Upper Mississippi River. Science

547 of The Total Environment 505: 435-445 DOI 10.1016/j.scitotenv.2014.10.012.

548 Su XM, Xue BB, Wang YY, Hashmi MZ, Lin HJ, Chen JR, Mei RW, Wang Z, Sun FQ.

549 2019. Bacterial community shifts evaluation in the sediments of Puyang River and its nitrogen

550 removal capabilities exploration by resuscitation promoting factor. Ecotoxicology and

551 Environmental Safety 179: 188-197 DOI 10.1016/j.ecoenv.2019.04.067.

552 Sun FL, Wang YS, Wu ML, Wang YT, Li QP. 2011. Spatial heterogeneity of bacterial

553 community structure in the sediments of the Pearl River estuary. Biologia 66: 574-584 DOI

554 10.2478/s11756-011-0066-6.

555 Wang JZ, Yang JH, Giesy JP, Zhang XW, Wu YK, Xie YW, Song C, Ren C, Yu HX. 2016.

556 Using in situ bacterial communities to monitor contaminants in river sediments. Environmental

557 Pollution 212:348-357 DOI 10.1016/j.envpol.2016.01.031. 
558 Wang L, Zhang J, Li HL, Yang H, Peng C, Lu ZS. 2018. Shift in the microbial community

559 composition of surface water and sediment along an urban river. Science of The Total

560 Environment 627:600-612 DOI 10.1016/j.scitotenv.2018.01.203.

561 Wang P, Chen B, Yuan RQ, Li CQ, Li Y. 2016. Characteristics of aquatic bacterial community

562 and the influencing factors in an urban river. Science of the Total Environment 569: 382-389 DOI

563 10.1016/j.scitotenv.2016.06.130.

564 Wang PF, Wang X, Wang C, Miao LZ, Hou J, Yuan QS. 2017. Shift in bacterioplankton

565 diversity and structure: Influence of anthropogenic disturbances along the Yarlung Tsangpo River

566 on the Tibetan Plateau, China. Scientific Reports 7(1):12529 DOI 10.1038/s41598-017-12893-4.

567 Wang Q, Garrity GM, Tiedje JM, Cole JR. 2007. Naive Bayesian classifier for rapid

568 assignment of rRNA sequences into the new bacterial taxonomy. Applied Environmental

569 Microbiology 73:5261-5267 DOI 10.1128/AEM.00062-07.

570 Wang SH. 2012. Manual for sediment mass investigation and assessment. Science Press, Beijing.

571 Wéry N, Lhoutellier C, Ducray F, Delgenès JP, Godon JJ. 2008. Behaviour of pathogenic and

572 indicator bacteria during urban wastewater treatment and sludge composting, as revealed by

573 quantitative PCR. Water Research 42: 53-62 DOI 10.1016/j.watres.2007.06.048.

574 Xia N, Xia XH, Liu T, Hu LJ, Zhu BT, Zhang XT, Dong JW. 2014. Characteristics of bacterial

575 community in the water and surface sediment of the Yellow River, China, the largest turbid river

576 in the world. Journal of Soils and Sediments 14:1894-904 DOI 10.1007/s11368-014-0974-5.

577 Yan QY, Bi YH, Deng Y, He ZL, Wu LY, VanNostrand JD, Shi Z, Li JJ, Wang X, Hu ZY,

578 Yu YH, Zhou JZ. 2015. Impacts of the Three Gorges Dam on microbial structure and potential

579 function. Scientific Reports 5:8605 DOI 10.1038/srep08605. 
580 Yang YZ, Li SG, Gao YC, Chen YY, Zhan AB. Environment-driven geographical distribution

581 of bacterial communities and identification of indicator taxa in Songhua River. Ecological

582 Indicators 101: 62-70 DOI 10.1016/j.ecolind.2018.12.047.

583 Zhang MZ, Wu ZJ, Sun QY, Ding YX, Sun LL. 2019. The spatial and seasonal variations of

584 bacterial community structure and influencing factors in river sediments. Journal of

585 Environmental Management 248:109293 DOI 10.1016/j.jenvman.2019.109293.

586 Zhang WL, Lei MT, Li Y, Wang PF, Wang C, Gao Y, Wu HN, Xu C, Niu LH, Wang LF,

587 Zhang HJ. 2019. Determination of vertical and horizontal assemblage drivers of bacterial

588 community in a heavily polluted urban river. Water Research 161:98-107 DOI

589 10.1016/j.watres.2019.05.107.

590 Zhang WL, Li Y, Wang C, Wang PF, Hou J, Yu ZB, Niu LH, Wang LQ, Wang J. 2016.

591 Modeling the biodegradation of bacterial community assembly linked antibiotics in river sediment

592 using a deterministic-stochastic combined model. Environmental Science and Technology 50

593 (16): 8788-8798 DOI 10.1021/acs.est.6b01573.

594 Zhang X, Yan QY, Yu YH, Dai LL. 2014. Spatiotemporal pattern of bacterioplankton in

595 Donghu Lake. Chinese Journal Oceanology and Limnology 32: 554-564 DOI 10.1007/s00343-

596 014-3037-2.

597 Zheng G, Yampara-Iquise H, Jones JE, Carson CA. 2009. Development of Faecalibacterium

598 16S rRNA gene marker for identification of human faeces. Journal of Applied Microbiology 106:

599 634-641 DOI 10.1111/j.1365-2672.2008.04037.x.

600 Zhu CM, Zhang JY, Nawaz MZ, Mahboob S, Al-Ghanim KA, Khan IA, Lu ZH, Chen T.

601 2019. Seasonal succession and spatial distribution of bacterial community structure in a eutrophic 
602 freshwater lake, lake taihu. The Science of the Total Environment 699(15): 29-40 DOI

603 10.1016/j.scitotenv.2019.03.087.

604 
Figure 1

Location of sampling sites in Liangtan River. 


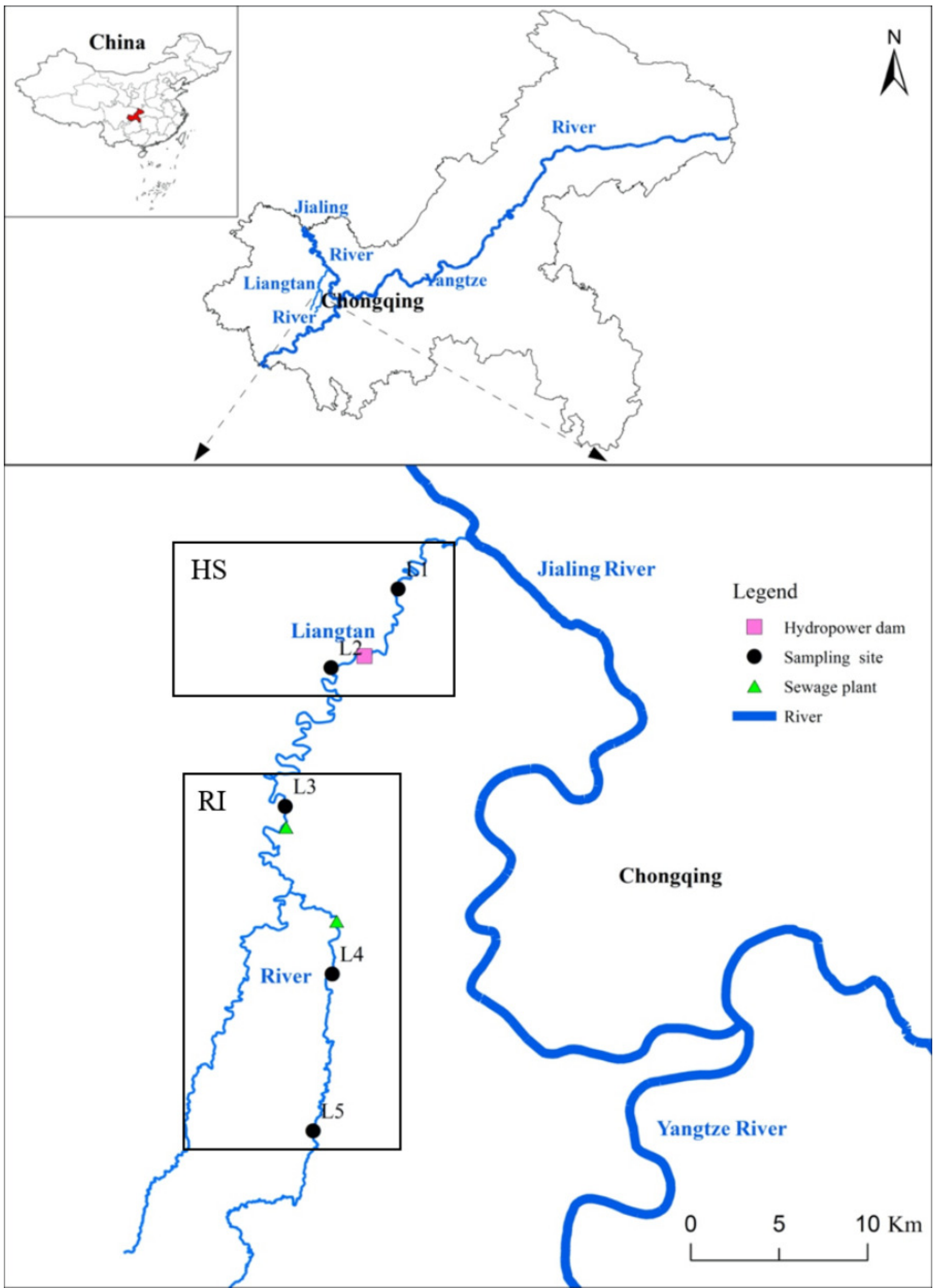


Figure 2

Comparisons of Chaol richness estimator, Shannon diversity index, and Simpson evenness index of planktonic and sediment bacterial communities in HS and RI areas. Different lowercase letters indicate significant differences $(P<0.05)$ in mean values.
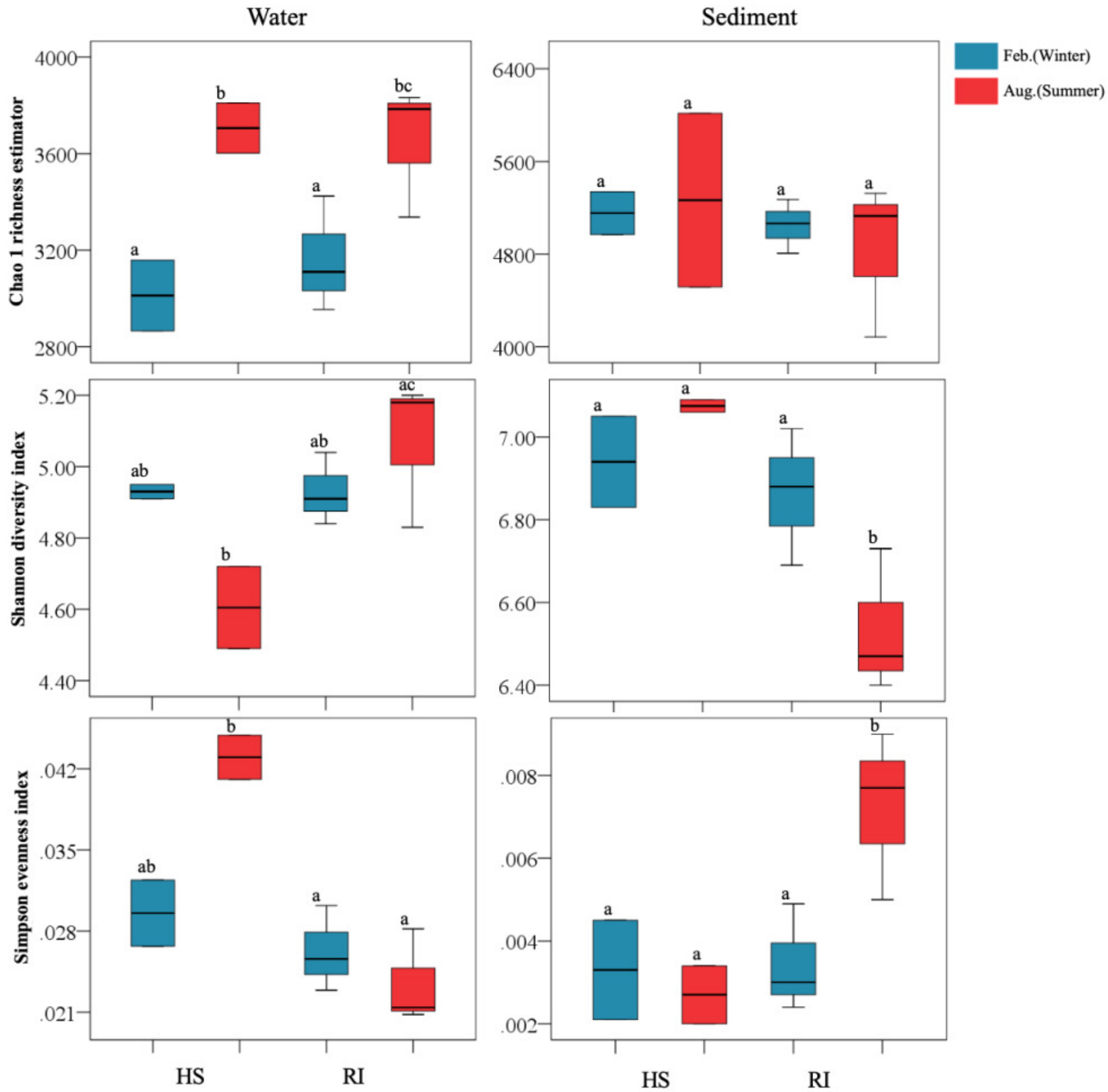
Figure 3

Principal coordinates analysis (PCOA) for spatiotemporal variations of planktonic and sediment bacterial communities according to Bray-Curtis distance matrices.Green circle symbols represent the February water samples from sites L1-L5. Green triangle symb




Figure 4

Relative abundance of dominant bacterial phyla in waters and sediments derived from the sampling sites. Bacterial phyla with relative abundance less than $1 \%$ of in each sample are classified as others.

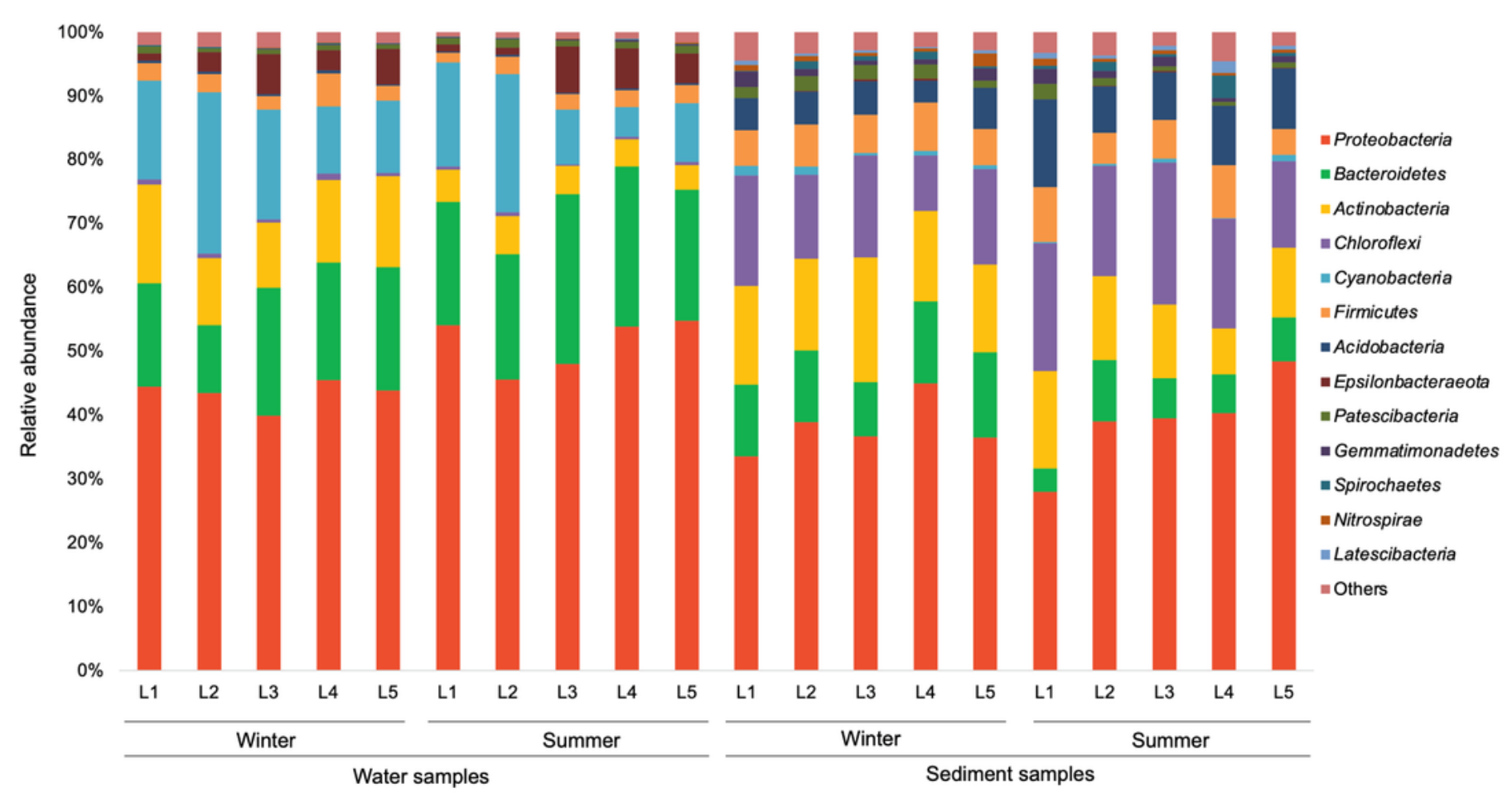


Figure 5

Relative abundance of proteobacterial classes in waters and sediments derived from the sampling sites. Unclassified Proteobacteria are classified as others.

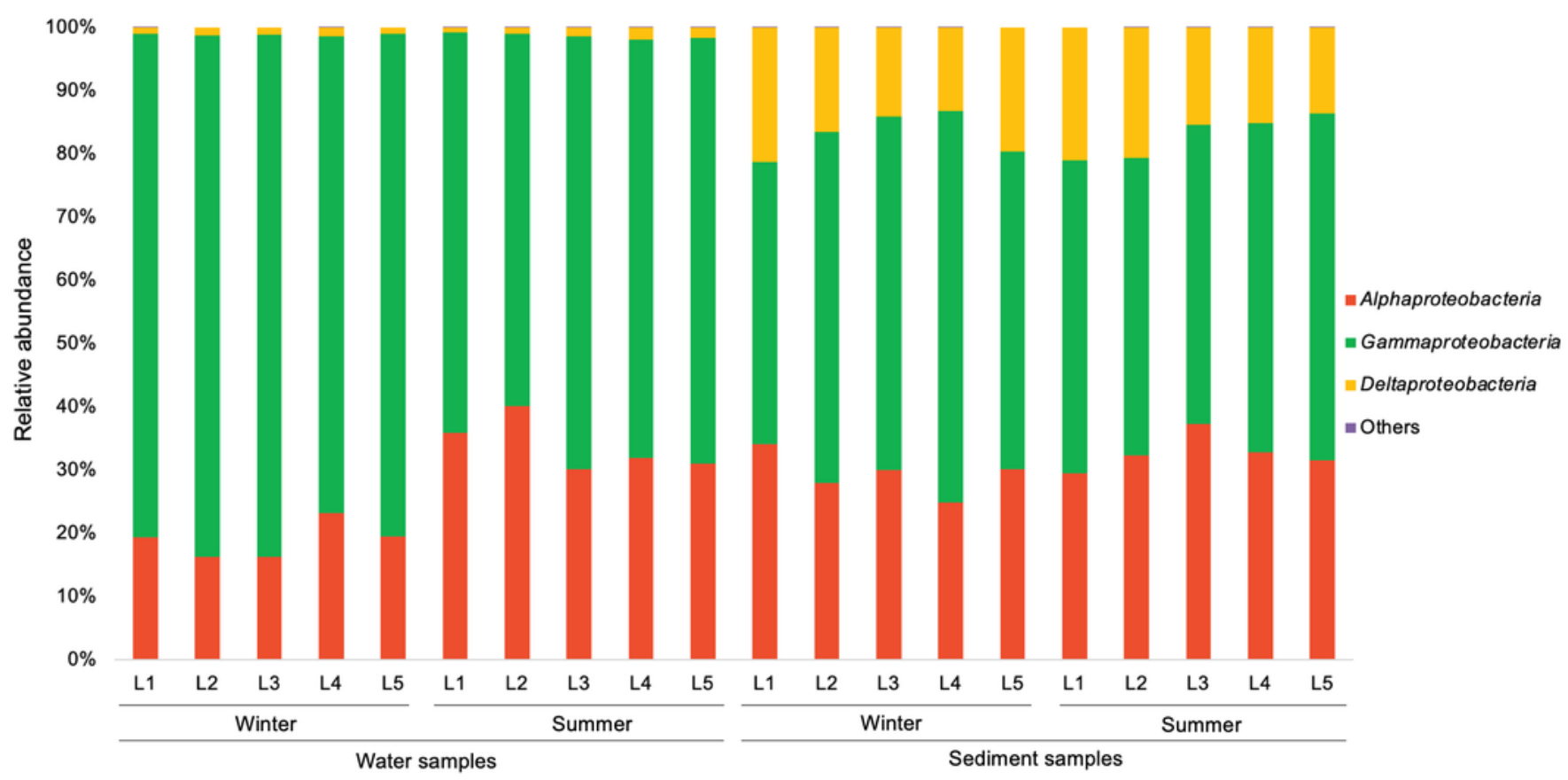


Figure 6

Redundancy analysis (RDA) for the first two principal dimensions of the relationships between planktonic bacterial OTU composition and water properties. Green triangle symbols represent the August water samples from sites L1-L5. Blue circle symbols repres 


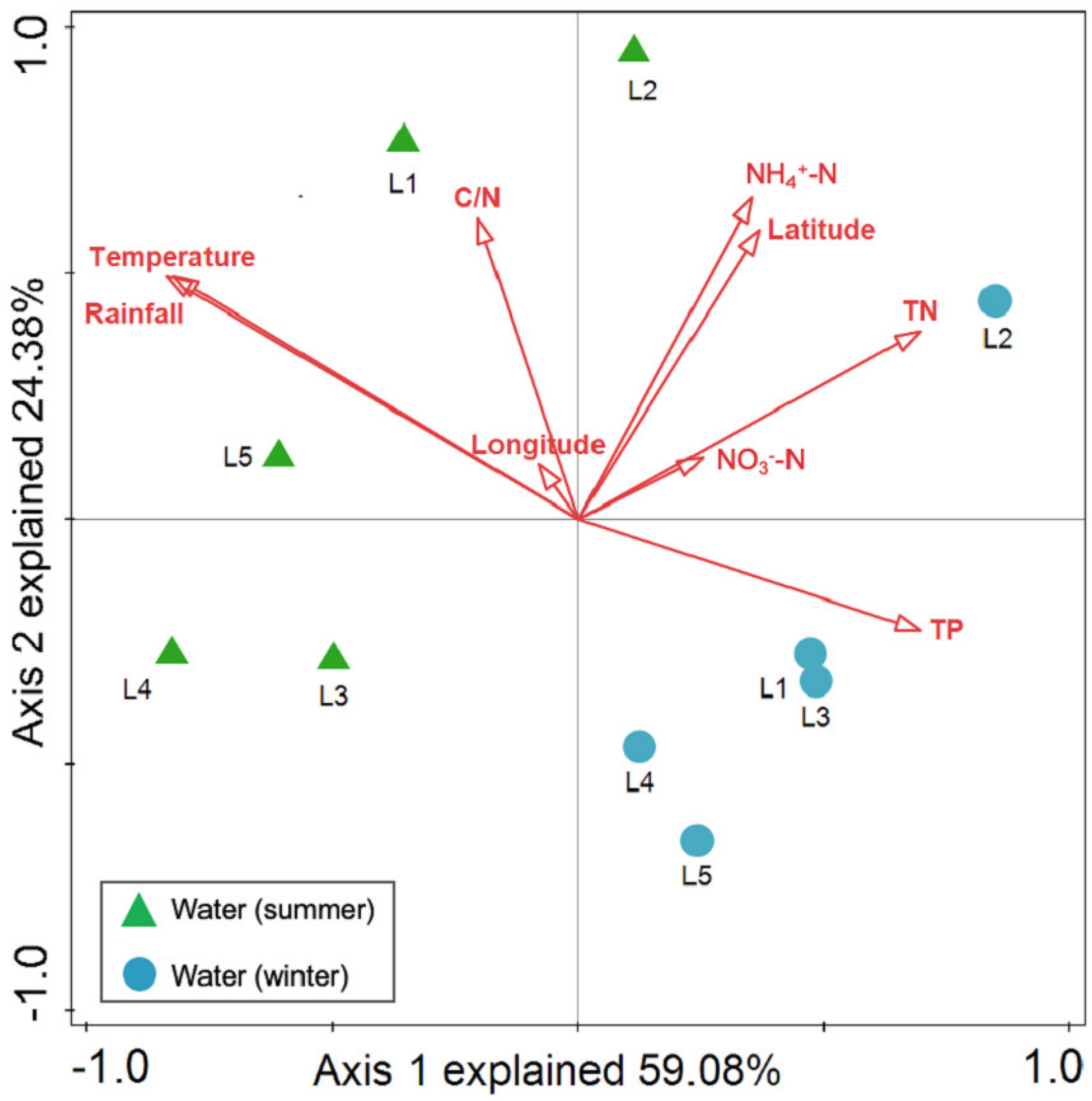




\section{Figure 7}

Variation partitioning analysis (VPA) of the effects of season, nutrients, and geographic distance on planktonic (a) and sediment (b) bacterial communities.

(a) Water

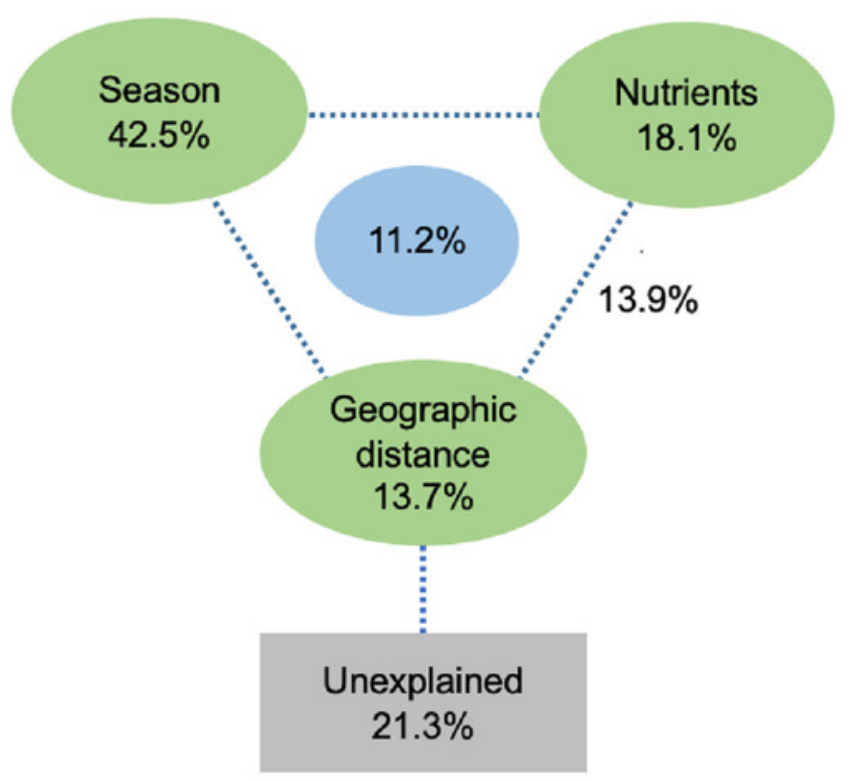

(b) Sediment

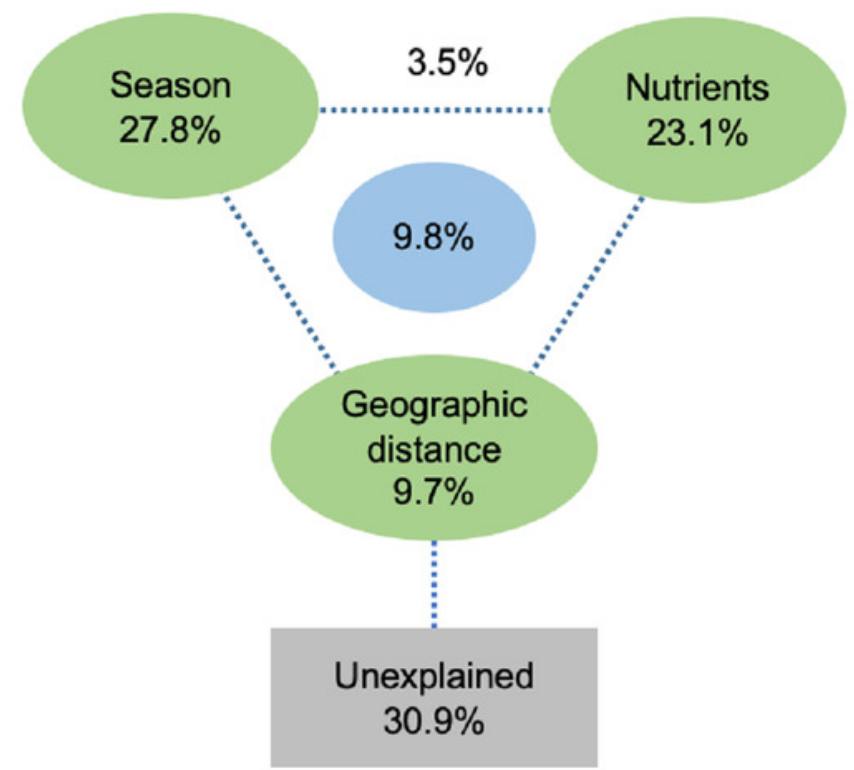


Figure 8

Redundancy analysis (RDA) for the first two principal dimensions of the relationships between sediment bacterial OTU composition and sediment properties. Green triangle symbols represent the August sediment samples from sites L1-L5. Blue circle symbols re 


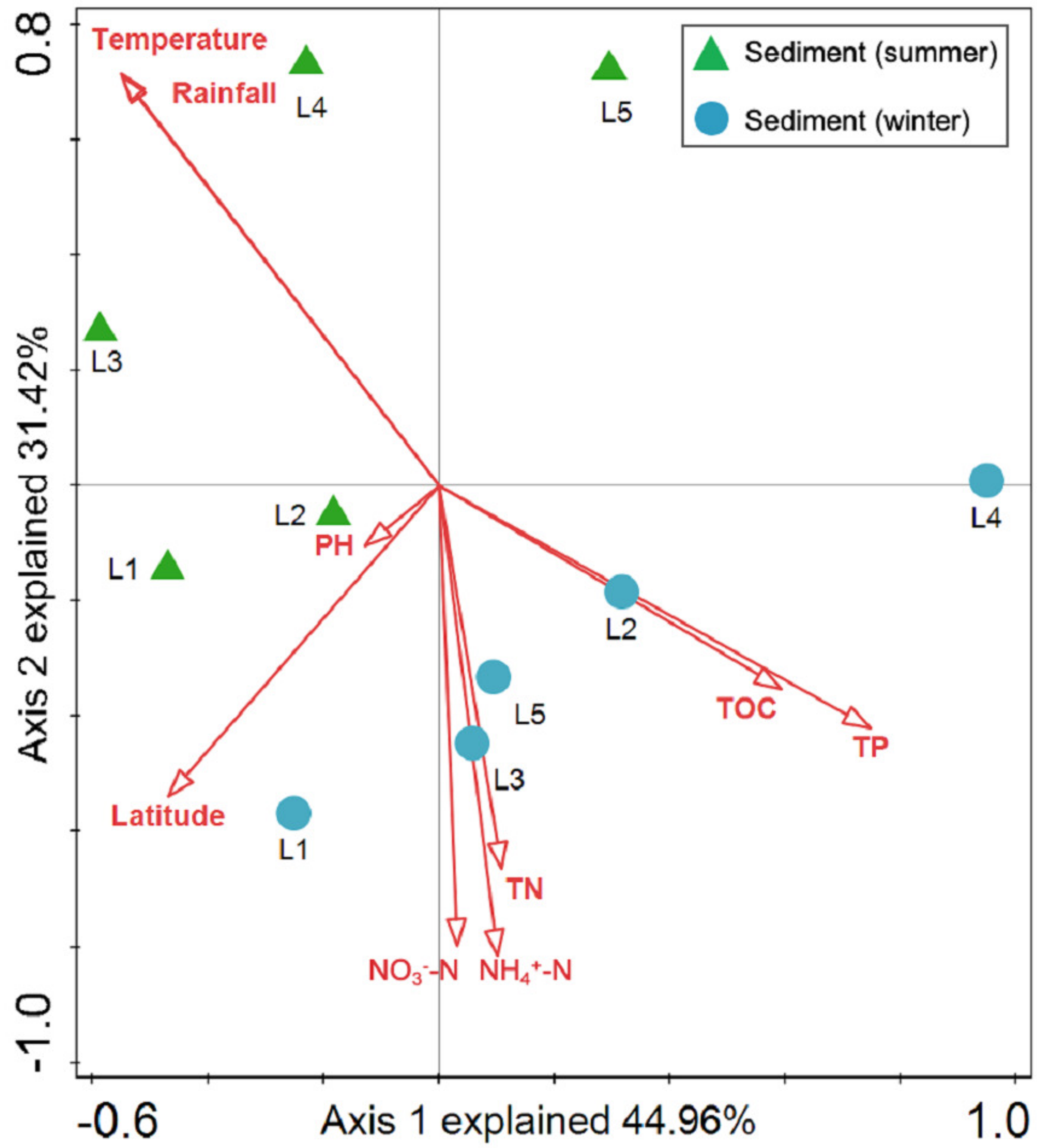




\section{Table $\mathbf{1}$ (on next page)}

Quantitative effects of seasons (winter or summer) and areas (HS or RI) on planktonic and sediment bacterial communities using permutational multivariate analysis of variance (PerMANOVA). 
1 Table 1 Quantitative effects of seasons (winter or summer) and areas (HS or RI) on planktonic and sediment bacterial communities

2 using permutational multivariate analysis of variance (PerMANOVA). $R^{2}$ value represents the proportion of the community variation

3 constrained by each variable and their interaction. $P$ value less than 0.05 means significant.

\begin{tabular}{lllll}
\hline \multirow{2}{*}{ Groups } & \multicolumn{2}{l}{ Water } & \multicolumn{2}{l}{ Sediment } \\
& \multicolumn{2}{l}{ (Water vs. sediment: $\left.R^{2}=0.561, P=\mathbf{0 . 0 0 1}\right)$} & $R^{2}$ & $P$ \\
\cline { 2 - 5 } & $R^{2}$ & $P$ & 0.197 & 0.063 \\
Season (winter vs. summer) & 0.731 & $\mathbf{0 . 0 1 1}$ & 0.345 & $\mathbf{0 . 0 0 6}$ \\
Area (HS vs. RI ) & 0.120 & 0.496 & 0.611 & $\mathbf{0 . 0 0 1}$ \\
Season $\times$ area & 0.886 & $\mathbf{0 . 0 0 2}$ & \\
\hline
\end{tabular}




\section{Table 2 (on next page)}

Comparisons of potential bacterial pathogen sequences at the genus level in waters and sediments derived from HS and RI areas. The data in bold indicate significant differences $(P<0.05)$ in mean values. 
1 Table 2 Comparisons of potential bacterial pathogen sequences at the genus level in waters and sediments derived from HS and RI

2 areas. The data in bold indicate significant differences $(\mathrm{P}<0.05)$ in mean values.

\begin{tabular}{|c|c|c|c|c|c|c|c|c|c|}
\hline \multirow{2}{*}{ Season } & \multirow{2}{*}{ Area } & \multirow{2}{*}{ Water/sediment } & \multicolumn{4}{|c|}{ Groups } & \multirow{2}{*}{ Water/sediment } & \multirow{2}{*}{ Area } & \multirow{2}{*}{ Season } \\
\hline & & & HS & RI & HS & RI & & & \\
\hline \multirow[t]{2}{*}{ Winter } & HS & Water & - & 0.024 & 0.089 & 0.123 & Sediment & HS & Winter \\
\hline & RI & Water & 0.019 & - & 0.002 & 0.228 & Sediment & RI & \\
\hline Summer & HS & Water & 0.148 & 0.217 & - & 0.007 & Sediment & HS & Summer \\
\hline
\end{tabular}

3 


\section{Table 3(on next page)}

Spearman rank correlation analysis of water environmental factors with the richness and diversity of planktonic bacterial community or the proportion of the major planktonic bacterial groups. The data in bold indicate significant differences. 
1 Table 3 Spearman rank correlation analysis of water environmental factors with the richness and diversity of bacterioplankton

2 community or the proportion of the major planktonic bacterial groups. The data in bold indicate significant differences.

\begin{tabular}{|c|c|c|c|c|c|c|c|}
\hline Parameters & $\mathrm{pH}$ & Temperature & $\mathrm{NH}_{4}^{+}-\mathrm{N}$ & $\mathrm{NO}_{3}{ }^{-}-\mathrm{N}$ & $\mathrm{TN}$ & $\mathrm{TP}$ & TOC \\
\hline OTUs & 0.012 & $0.669^{\mathrm{a}}$ & -0.103 & -0.067 & -0.382 & $-0.770^{b}$ & -0.139 \\
\hline Chaol estimator & 0.012 & $0.693^{\mathrm{a}}$ & -0.236 & 0.067 & -0.236 & $-0.770^{b}$ & -0.103 \\
\hline Shannon index & 0.255 & -0.264 & $-0.745^{a}$ & 0.358 & 0.115 & 0.345 & $-0.697^{a}$ \\
\hline Proteobacteria & -0.134 & $0.865^{b}$ & -0.188 & -0.127 & -0.370 & $-0.673^{a}$ & -0.115 \\
\hline Alphaproteobacteria & -0.158 & $\mathbf{0 . 8 5 3}^{\mathrm{b}}$ & 0.079 & -0.018 & -0.236 & $-0.794^{b}$ & 0.224 \\
\hline Gammaproteobacteria & 0.255 & -0.239 & -0.467 & 0.333 & 0.139 & 0.491 & -0.576 \\
\hline Bacteroidetes & -0.146 & 0.497 & -0.139 & -0.321 & $-0.673^{a}$ & $-0.709^{a}$ & -0.430 \\
\hline Actinobacteria & 0.182 & $-0.632^{a}$ & -0.006 & 0.200 & 0.382 & $0.648^{\mathrm{a}}$ & 0.176 \\
\hline Cyanobacteria & 0.292 & -0.485 & $0.721^{\mathrm{a}}$ & 0.030 & $0.661^{\mathrm{a}}$ & 0.394 & $0.636^{\mathrm{a}}$ \\
\hline Epsilonbacteraeota & -0.219 & -0.080 & -0.273 & -0.200 & -0.564 & -0.176 & -0.515 \\
\hline Firmicutes & 0.316 & -0.178 & -0.248 & 0.600 & 0.600 & 0.236 & -0.030 \\
\hline Patescibacteria & 0.365 & $0.669^{a}$ & -0.006 & -0.006 & 0.042 & -0.576 & -0.055 \\
\hline
\end{tabular}

$3{ }^{\mathrm{a}}$ Correlation is significant at the 0.05 level

$4{ }^{\mathrm{b}}$ Correlation is significant at the 0.01 level 


\section{Table 4 (on next page)}

Spearman rank correlation analysis of sediment environmental factors with the richness and diversity of sediment bacterial community or the proportion of the major sediment bacterial groups. The data in bold indicate significant differences. 
1 Table 4 Spearman rank correlation analysis of sediment environmental factors with the richness and diversity of sediment bacterial

2 community or the proportion of the major sediment bacterial groups. The data in bold indicate significant differences.

\begin{tabular}{|c|c|c|c|c|c|c|c|}
\hline Parameters & $\mathrm{pH}$ & Temperature & $\mathrm{NH}_{4}{ }^{+}-\mathrm{N}$ & $\mathrm{NO}_{3}{ }^{-}-\mathrm{N}$ & $\mathrm{TN}$ & $\mathrm{TP}$ & TOC \\
\hline OTUs & -0.103 & 0.299 & 0.030 & 0.176 & -0.018 & -0.309 & -0.297 \\
\hline Chaol estimator & -0.212 & 0.079 & 0.055 & 0.321 & 0.006 & -0.030 & -0.006 \\
\hline Shannon index & 0.430 & 0.177 & $0.709^{a}$ & $0.745^{\mathrm{a}}$ & $0.758^{\mathrm{a}}$ & -0.079 & -0.103 \\
\hline Proteobacteria & -0.479 & 0.128 & $-0.770^{a}$ & $-0.661^{a}$ & -0.600 & -0.030 & -0.030 \\
\hline Alphaproteobacteria & -0.042 & $0.695^{a}$ & -0.624 & -0.527 & -0.358 & $-0.733^{a}$ & $-0.709^{a}$ \\
\hline Gammaproteobacteria & -0.503 & -0.28 & -0.467 & -0.491 & -0.394 & 0.248 & 0.236 \\
\hline Deltaproteobacteria & $0.770^{b}$ & 0.488 & 0.455 & 0.515 & 0.539 & -0.236 & -0.164 \\
\hline Bacteroidetes & 0.103 & -0.622 & 0.539 & 0.467 & 0.309 & $0.842^{b}$ & $0.794^{b}$ \\
\hline Actinobacteria & -0.055 & -0.482 & $0.673^{a}$ & $0.636^{\mathrm{a}}$ & $0.648^{\mathrm{a}}$ & 0.358 & 0.261 \\
\hline Chloroflexi & 0.164 & $0.701^{\mathrm{a}}$ & -0.030 & 0.042 & 0.079 & $-0.782^{b}$ & $-0.758^{a}$ \\
\hline Firmicutes & -0.079 & 0.037 & -0.006 & -0.127 & -0.055 & 0.067 & 0.103 \\
\hline Acidobacteria & -0.055 & 0.305 & $-0.733^{a}$ & $-0.636^{a}$ & $-0.758^{a}$ & -0.515 & -0.430 \\
\hline Gemmatimonadetes & 0.552 & 0.171 & $0.782^{b}$ & $0.673^{a}$ & 0.612 & -0.127 & -0.103 \\
\hline Nitrospirae & 0.527 & -0.055 & $0.879^{b}$ & $0.709^{a}$ & 0.600 & 0.115 & 0.127 \\
\hline
\end{tabular}

$3{ }^{\mathrm{a}}$ Correlation is significant at the 0.05 level

$4{ }^{\mathrm{b}}$ Correlation is significant at the 0.01 level 
